AL IRFANI: Journal of Qur'anic and Tafsir (JQT)

| e-ISSN 2746-1025 | p-ISSN 2088-6829 |

DOI: 10.51700/irfani.v1i02

homepage journal: https://journal.staidk.ac.id/index.php/irfani

\title{
ANALISIS PEMIKIRAN HERMENEUTIKA HADIS YUSUF AL-QARDHAWI
}

\author{
Muhammad Zainul Hasan *1 \\ Affiliasi: Pascasarjana UIN Sunan Kalijaga Yogyakarta
}

\begin{tabular}{|c|c|}
\hline & Abstract \\
\hline $\begin{array}{l}\text { Keywords: } \\
\text { Thought } \\
\text { Hadith } \\
\text { Hermeneutics }\end{array}$ & $\begin{array}{l}\text { In order to obtain a good and comprehensive understanding of hadith with the } \\
\text { intention of avoiding a textual and not grounded understanding Yusuf al- } \\
\text { Qardhawi offers a solutive concept and methodology in understanding the } \\
\text { Prophet's hadith. This research is a study of literature, especially examining the } \\
\text { method of understanding hadiths offered by al-Qardhawi in Kaifa Nata'amalu } \\
\text { Ma'a As-Sunnah An-Nabawiyyah. In addition, researchers also used other } \\
\text { literature as a complementary addition. The method of analysis used in this } \\
\text { study is hermeneutic analysis, in which researchers describe objects that are } \\
\text { systematically reviewed and then analyzed with a hermeneutic approach. Come } \\
\text { to the conclusion that the most important point we get from the offer given by } \\
\text { al-Qardhawi is how we understand and realize while relive the hadith of the } \\
\text { Prophet who shalih likulli zaman wa makan. What al-Qardhawi has offered in } \\
\text { understanding the Prophet's hadith with the points mentioned in this study is a } \\
\text { form of hermeneutic work, although al-Qardhawi does not directly } \\
\text { demonstrate his method as an offer of hermeneutic methods. }\end{array}$ \\
\hline
\end{tabular}

\begin{tabular}{ll} 
& Abstrak \\
\hline Kata Kunci : & Untuk mendapatkan pemahaman hadis yang baik dan komprehensif dengan \\
Pemikiran & maksud agar terhindar dari pemahaman yang tekstual dan tidak membumi \\
Hadis & Yusuf al-Qardhawi menawarkan konsep dan metodologi yang solutif dalam \\
Hermeneutika & memahami hadis Nabi. Penelitian ini berupa studi literatur khususnya mengkaji \\
& tentang metode pemahaman hadis yang tiwarkan oleh al-Qardhawi dalam \\
& Kaifa Nata'amalu Ma'a As-Sunnah An-Nabawiyyah. Selain itu, peneliti juga \\
\hline
\end{tabular}

${ }^{1}$ Corresponden to the author: Pascasarjana UIN Sunan Kalijaga Yogyakarta: email address: acanhasan8@gamil.com

e-ISSN 2746-1025 |p-ISSN 2088-6829 | h. 33

homepage journal: https://journal.staidk.ac.id/index.php/irfani 
menggunakan literatur lain sebagai tambahan pelengkap. Metode analisis yang digunakan dalam penelitian ini ialah analisis hermeneutis, dimana peneliti mendeskripsikan objek yang dikaji secara sistematis lalu kemudian dianalisis dengan pendekatan hermeneutika. Sampai pada kesimpulan bahwa poin terpenting yang kita dapatkan dari tawaran yang diberikan oleh al-Qardhawi ialah bagaimana kita memahami dan mengaktualisasikan sekaligus menghidupkaan kembali hadis Nabi yang shalih likulli zaman wa makan. Apa yang telah ditawarkan oleh al-Qardhawi dalam memahami hadis Nabi dengan poin-poin yang telah disebutkan didalam penelitian ini merupakan bentuk kerja hermenetik, meskipun al-Qardhawi tidak secara langsung mempertunjukkan metodenya sebagai tawaran metode hermeneutika.

\section{Pendahuluan}

Hadis merupakan sumber otoritatif umat Islam setelah al-Qur'an, hadis di samping sebagai sumber rujukan kedua sekaligus mempunyai fungsi sebagai penjelas bagi al-Qur'an yang yang bermakna global (umum). Maka dalam kajian hadis ada problem yang urgen, seperti : (1) problemproblem baru yang muncul, (2) pendekatan yang selama ini agaknya kurang bisa menjawab tantangan atau persoalan yang muncul pada era modern, (3) munculnya pemikiran dan yang memberikan alternatif yang sekiranya perlu disosialisasi dan dikritisi. ${ }^{2}$ Selama ini kajian atau penelitian terhadap hadis Nabi yang dilakukan oleh ulama terdahulu hanya disibukkan dengan nilai atau tingkatan hadis dari segi sanad, sehingga pada ahirnya ajaran Islam yang bersumber dari hadis Nabi tidak bisa menjawab tantangan masa depan.

Saudi Arabia kultur dan budaya tempat awal terbentuknya teks al-Qur'an maupun hadis dengan kultur budaya dan georafis pada suatu tempat yang berbeda tentu juga berdampak pada beragamnya masalah pemahaman (understanding) dan pemaknaan (meaning) teks yang berkembang pula. ${ }^{3}$ Untuk mejawab tantangan tersebut kiranya perlu pendekatan baru dalam memahami hadis yang obyektif-progresif sehingga kandungan teks hadis menemukan relevansinya disetiap kultur budaya dan georafis pada suatu tempat yang berbeda. Pola pembacaan teks seperti ini penting untuk dikembangkan sehinggga kita terhindar dari pemahaman hadis yang tekstual. Oleh karena itu pendekatan hermeneutika setidaknya menjadi jalan keluar (solusi) interpretasi hadis, sebab tawaran yang diberikan oleh hermenutika berangkat dari analisis psiko- historis-

\footnotetext{
2 Siti Fatimah, Hermeneutika Hadis : Tinjauan Pemikiran Yusuf al-Qardhawi dalam Memahami Hadis, Jurnal REFLEKSI, Vol. 16, No. 1, 2017, 84.

${ }^{3}$ Saifuddin Zuhri Qudsy, Subkhani Kusuma Dewi, Living Hadis Praktik, Resepsi, Teks, dan Transmisi, (Yogyakarta : QMedia, 2018), 10.
} 
sosiologis, sehingga yang ingin dijelaskan ialah bagaimana hadis yang disampaikan pada waktu dan tempat yang berbeda (masa Nabi Muhammad) kemudian difahami dan ditafsirkan dalam realitas sosial kekinian.

Pada dasarnya para pemikir muslim banyak yang sudah menggunakan pola pembacaan hermeneutika, seperti, al-Ghzali, Fazlur Rahman, Abid al-Jabiri, Nasr Hamid Abu Zayd, Muhammad Sabesthari, Amina Wadud, Syuhudu Ismail, Muhammad Syahrur, Abdullah Saeed, dan yang lainya. ${ }^{4}$ Salah satu yang menggunakan pembacaan hermeneutika dalam memahami hadis ialah Yusuf alQardhawi. Tulisan ini akan mengkaji bagaimana pemikiran al-Qardhawi tentang hadis Nabi, yang kemudian dianalisis dengan pendekatan hermeneutika.

\section{Perjalanan Intelektual Yusuf al-Qardhawi}

Yusuf al-Qardhawi merupakan seorang ulama sekaligus cendikiawan muslim yang masyhur dengan keilmuan dan dakwahnya. Yusuf al-Qardhawi lahir di desa kecil bernama Shafth Turaab di tengah Delta Sungai Nil Mesir, pada 09 September 1926. ${ }^{5}$ Semenjak kecil al-Qardhawi telah menjadi seorang anak yatim karena pada umur dua tahun ia sudah ditinggalkan oleh orang tuanya. Lantas kemudian ia diasuh oleh pamannya. Semenjak kecil kecerdasan al-Qardhawi sudah terlihat, ini terbukti ketika menginjak umur 10 tahun, ia sudah mampu menghafal al-Qur'an. Menamatkan pendidikan di Ma'had Thantha dan Ma'had Tsanawi dan melanjutkan ke Universitas al-Azhar di Fakultas Ushuluddin dan lulus tahun 1952, ia mendapat gelar doktornya pada tahun 1972 dengan disertasi "Zakat dan Dampaknya dalam Penanggulangan Kemiskinan", yang kemudian disempurnakan menjadi Fiqh Zakat. ${ }^{6}$

Selama masa hidupnya al-Qardhawi termasuk salah satu ulama yang sangat produktif, terlihat dari jejak perjalanan dahwaknya dan banyak karya-karya tulis yang dihasilakan, kemahirannya dalam berbagai disiplin ilmu terbukti dari berbagai karyanya dari mulai tafsir, hadis, fiqh dsb. Salah satu karya monumentalnya dalam bidang hadis ialah Kaifa Nata'amalu Ma'a As-Sunnah AnNabawiyyah, yang kemudian diterjemahkan kedalam bahasa Indonesia oleh Muhammad al-Baqir. Dalam karya monumentalnya tersebut al-Qardhawi menjelaskan bagaimana prinsip dasar dalam memahami hadis Nabi, sehingga karyanya tersebut memungkinkan kita memahami hadis Nabi

\footnotetext{
${ }^{4}$ Kurdi dkk, Hermeneutika al-Qu'ran dan Hadis, disunting oleh Sahiron Syamsuddin (Yogyakarta: eLSAQ Press, 2010), v.

${ }^{5}$ Yusuf al-Qardhawi, al-Halal wa al-Haram Fi al-Islam, Terj Tatam Wijaya, (Yogyakarta : Maktabah Wahbah, 2017), 878.

${ }^{6}$ Sulaiman ibn Shalih, Al-Qaradhawi fil Mizan, (Riyadl: Dar al-Jawab, t.t), 8.
} 
secara kontekstual sehinnga pemahaman hadis shalih li Kulli zaman wa makan dan terhindar dari pemahaman hadis yang tekstual dan harfiyah. Karya-karya lain al-Qardhawi adalah :7

Bidang ilmu al-Qur'an dan as-sunnah

- As-Shabar fil Qur'an

- Al-Aql wa al-ilm fil Qur'an

- Kaifa Nata'amalu Ma'a As-Sunnah An-Nabawiyyah

- Kaifa Nata'amalu Ma'al Qur'anil azhim

Bidang fiqh dan ushul fiqh

- Al-halal wa al-haram fi al-islam

- Taisir al-fiqh : fiqh as-shiyam

- Fatawi mu'ashirah

- Al-ijtihad fi as-syariyah al-islamiyah

Bidang akidah islam

- Wujudullah

- Haqiqah at-tauhid

Bidang pendidikan dan dakwah

- Al-waqt fi hayati al-muslim

- Tsaqafatud da'iyah

- At-tarbiyah al-islamiyah wa madrasah hasan al-bana

- Ar-rasul wa al-ilm

Bidang ekonomi islam

- Fiqh az-zakat

- Fawa'id al-bunuk hiya ar-riba al-haram

- Musykilat al-faqr wa kaifa ala jaha al-islam

\section{Metode Pemahaman Hadis al-Qardhawi}

Untuk mendapatkan pemahaman yang baik serta komprehensif mengenai hadis Nabi dan untuk menghindari kita agar tidak terjebak pada pemahaman terhadap teks-teks hadis yang bersifat tekstual dan tidak membumi. Yusuf al-Qardhawi menawarkan delapan langkah dalam memahami hadis Nabi, yang sekiranya sangat penting untuk dipertimbangkan dalam uapaya kita menginternalisasi hadis nabi yang shalih likulli zaman wa makan. Langkah-langkah tersebut adalah :

\footnotetext{
${ }^{7}$ Syekh Khalid as-Said, khitab Yusuf al-Qaradhawi, (Kairo : Maktabah Wahbah, 1997), 317.
}

e-ISSN 2746-1025 |p-ISSN 2088-6829 | h. 36 
Memahami Hadis Sesuai Petunjuk al-Qur'an

Metode semacam ini sangat mendasar mengingat al-Qur'an adalah sumber utama dalam Islam dalam berbagai bidang, ibadah, hukum, muamalah dan lain sebagainya, sedangkan hadis menempati posisi kedua setelah al-Qur'an yang berpungsi sebagai penjelas bagi al-Qur'an yang bersfiat teoritis dan disatu sisi hadis juga aplikasi praktis terhadap al-Qur'an itu sendiri. ${ }^{8}$ Oleh karena itu menurut al-Qardhawi tidaklah mungkin sesuatu yang merupakan pemberi penjelasan bertentangan dengan apa yang hendak dijelaskan. Maka penjelasan yang bersumber dari Nabi Saw, selalu senantiasa berkisar di seputar al-Qur'an dan tidak mungkin akan melanggarnya. ${ }^{9}$

Dan jika ternyata ditemukan pertentangan antara hadis dengan ayat al-Qur'an yang sudah jelas dan pasti (muhkamat) maka boleh jadi hadis tersebut menurut al-Qardhawi berkualitas tidah shahih, boleh jadi juga pertentangan tersebut muncul disebabkan oleh pemahaman kita yang kurang tepat atau boleh jadi yang dikira bertentanagan hanyalah bersifat semu dan bukan pertentanakan yang hakiki. al-Qardhawi memberikan sebuah contoh hadis yang bertentangan dengan ayat al-Qur'an yaitu hadis tentang Gharanig. Menurut al-Qardhawi hadis tersebut harus ditolak karena bertentangan dengan al-Qur'an surat an-Najm ayat 19-23.

\section{Menghimpun Hadis-hadis yang setema}

Untuk berhasil memahami hadis Nabi dengan benar dan komprehensif, menurut al-Qardhawi kita harus menetukan atau menghimpun hadis-haids shahih yang berkaitan dengan satu tema tertentu. Kemudian mengembalikan hadis-hadis yang bermakan samar (mutasyabih) kepada hadis yang bermakna muhkam, mengaitkan yang muthlaq dengan yang muqayyad, dan menafsirkan hadis yang bermakna $a m^{\prime}$ dengan yang khash. Dengan cara demikian kita dapat mengerti maksud dari sebuah hadis dengan lebih jelas dan tidak dipertentangkan antara hadis yang satu dengan yang lainnya. ${ }^{10}$

Dalam hal ini al-Qardhawi memberikan contoh sebuah hadis yang berbicara tentang larangan menggunakan sarung sampai dengan di bawah mata kaki, yang mengandung ancaman cukup keras terhadap pelakunya. Dalam masalah ini, jika seseorang ingin memahami sebuah hadis maka ia harus menghimpun semua hadis-hadis yang berkaitan dengan orang-orang yang menggunakan sarung sampai dengan bawah mata kaki tanpa dibarangi dengan rasa sombong dan hadis-hadis

\footnotetext{
8 M. Alim Khoiri, Interaksi Dan Pemahaman Hadis (Telaah Hermeneutis Pemikiran Yusuf al-Qaradawi), Jurnal Universum, Vol. 12, No. 1, 2018, 33.

${ }^{9}$ Yusuf al-Qardhawi, Bagaimana Memahami Hadis Nabi, terj Muhammad al-Baqir, (Bandung : Karisma, 1993 ), 92.

${ }^{10}$ Yusuf al-Qardhawi, Bagaimana Memahami Hadis Nabi..., 106.
} 
lain yang berbicara tentang orang-orang yang menggunakan sarung sampai dengan bawah mata kaki yang dibarangi dengan rasa sombong. Dalam masalah ini juga al-Qardhawi mengutip pendapat para ulama hadis dalam menjelasakan tema tersebut, diantaranya adalah Ibnu Hajar dan imam an-Nawawi. Dapat disimpulkan bahwa hadis yang membahas tentang ancaman bagi penggunaan sarung dibawah mata kaki terbatas pada mereka yang sombong sebagai motivasi dari tindakannya tersebut. Itulah mereka yang diancam dengan hukuman yang keras.

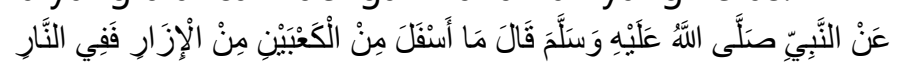

Nabi shallallahu 'alaihi wasallam beliau bersabda: "Barangsiapa menjulurkan kain sarungnya hingga dibawah mata kaki, maka tempatnya adalah neraka."(HR. Bukhari - 5341).

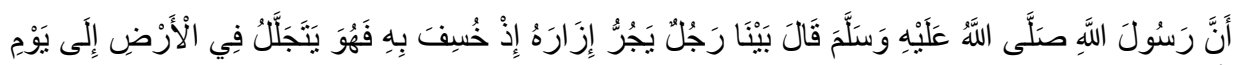

$$
\begin{aligned}
& \text { الْقِيَامَةِِ }
\end{aligned}
$$

Bahwa Rasulullah shallallahu 'alaihi wasallam bersabda: "Katika ada seseorang yang menjulurkan kain sarungnya maka dia akan berguncang-guncang (diadzab) di perut bumi hingga datangnya hari Kiamat." (HR. Bukhari - 5344)

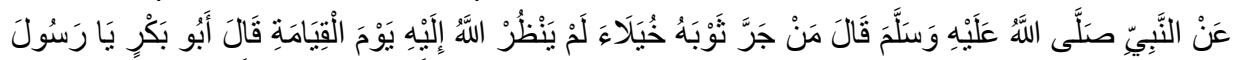

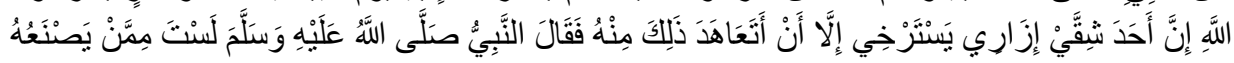
خُبَلَاءَ

Nabi shallallahu 'alaihi wasallam beliau bersabda: "Siapa yang menjulurkan pakaiannya (hingga ke bawah mata kaki) dengan sombong, maka Allah tidak akan melihatnya pada hari Kiamat kelak." Lalu Abu Bakar berkata; "Wahai Rasulullah, sesungguhnya salah satu dari sarungku terkadang turun sendiri, kecuali jika aku selalu menjaganya?" lalu Nabi shallallahu 'alaihi wasallam bersabda: "Engkau bukan termasuk orang yang melakukan hal itu karena sombong." (HR. Bukhari - 5338)

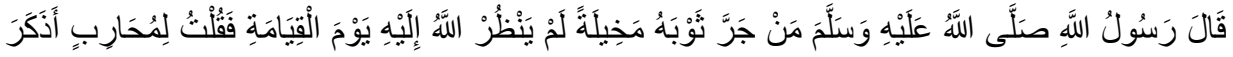

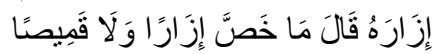
Rasulullah shallallahu 'alaihi wasallam bersabda: "Barangsiapa menjulurkan kainnya karena sombong, maka Allah tidak akan melihatnya pada hari Kiamat kelak." Lalu tanyaku kepada Muharib; "Apakah beliau menyebutkan kain sarung?" dia menjawab; "Beliau tidak mengkhususkan kain sarung ataukah jubah." (HR. Bukhari - 5345)

Pengabungan atau Pentarjihan antara Hadis-hadis yang (Tampaknya) Bertentangan 
Pada dasarnya teks-teks keagamaan (al-Quran dan Hadis) tidak mungkin saling bertentangan, sebab menurut al-Qardhawi kebenaran tidak akan bertentangan dengan kebenaran. Oleh karena itu apabila dijumpai adanya pertentangan, maka hal tersebut menurut al-Qardhawi hanya sebatas tampak lauarnya saja, bukan dalam kenyataan yang hakiki. Dalam menyikapi teks-teks keagamaan (hadis) yang tampaknya bertentangan al-Qardhawi menawarkan untuk melakukan kompromi atau dengan cara menggabungkan atau menyesuaikan antara kedua nash, tanpa harus memaksakan atau mengada-ngada, dengan demikian keduanya dapat diamalkan, maka yang demikain itu menurut al-Qardhawi lebih utama dari pada melakukan pentarjihan antara keduanya. Sebab pentarjihan menurut al-Qardhawi mengabaikan salah satu dari keduanya sementara mengutamakan yang lainnya. ${ }^{11}$

Melakukan kompromi atau dengan cara menggabungkan atau menyesuaikan antara kedua nash didahulukan sebelum pentarjihan menurut al-Qardhawi termasuk hal yang sangat penting dalam memahami hadis dengan baik. Apabila ditemukan hadis yang sekiranya tidak bisa dikompromikan atau tidak mungkin menggabungkan antara dua hadis atau berbagai hadis yang pada zahirnya tampak bertentangan, barulah menurut al-Qardhawi diupayakan pentarjihan, yaitu mentarjih (memenangkan) salah satu darinya dengan berbagai alasan pentarjihan yang telah ditentukan oleh para ulama. ${ }^{12}$ Berkaitan dengan masalah ini al-Qardhawi memberikan contoh sebuah hadis tentang pelarangan ziarah kubur bagi wanita. Hadis tersebut berbunyi :

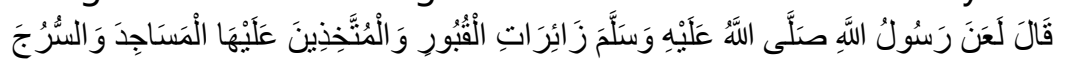

"Rasulullah shallallahu 'alaihi wasallam melaknat para wanita peziarah kubur dan mereka yang menjadikan kuburan sebagai masjid serta menyalakan lampu didalamnya". (HR. Ahmad - 1926).

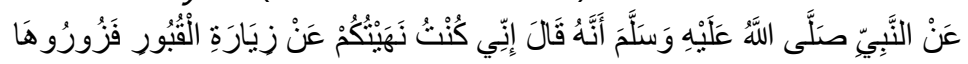

Nabi shallallahu 'alaihi wasallam bahwa beliau bersabda: "Sesungguhnya aku pernah melarang ziarah kubur, namun sekarang berziarahlah. (HR. Ahmad - 4092).

\section{Memahami Hadis sesuai dengan latar belakang, situasi, kondisi serta tujuan}

Untuk mendapatkan pemahaman terhadap sebuah hadis yang baik dan komprehensif tidak akan sempurna jika pemahaman terhadap hadis tersebut hanya sebatas kajian teks semata, tentu akan lebih mendalam lagi jika kajian kita ditambahkan dengan sebab-sebab khusus yang melatarbelakangi diucapkannya suatu hadis atau kaitannya dengan suatu 'illat (alasan, sebab)

\footnotetext{
${ }^{11}$ Yusuf al-Qardhawi, Bagaimana Memahami Hadis Nabi . . , , 118.

12 Yusuf al-Qardhawi, Bagaimana Memahami Hadis Nabi . . , 122.
} 
tertentu yang dinyatakan dalam hadis tersebut secara langsung atau dapat dipahami dari kejadian yang menyertainya. ${ }^{13}$ Sebagaimana dengan al-Quran untuk memahami kandungan makna dari sebuah ayat al-Qur'an diperlukan pemahaman tentang asbabun nuzul, yaitu sebab-sebab khsus yang melatarbelakangi turunnya ayat al-Qur'an. Begitu juga dengan hadis Nabi untuk memahami sebuah hadis seseorang perlu pengetahuan tentang asbabul wurud.

Menurut al-Qardhawi siapa saja yang ingin meneliti sebuah hadis secara seksama, pasti akan menemukan bahwa diantara hadis-hadis yang yang teruacapkan berkaitan dengan kondisi temporer khusus, demi suatu maslahat yang ingin dicapai atau mudarat yang ingin dicegah, atau mengatasi suatu problem yang timbul pada waktu itu. Dalam hal ini al-Qardhawi memberikan sebuah hadis tentang "kalian lebih mengerti urusan dunia kalian" sebagai contoh dari masalah tersebut.

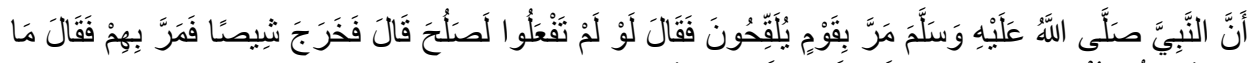

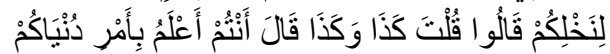

$$
\begin{aligned}
& \text { Nabi shallallahu 'alaihi wasallam pernah melewati suatu kaum yang } \\
& \text { sedang mengawinkan pohon kurma lalu beliau bersabda: "Sekiranya } \\
& \text { mereka tidak melakukannya, kurma itu akan (tetap) baik." Tapi setelah } \\
& \text { itu, ternyata kurma tersebut tumbuh dalam keadaan rusak. Hingga suatu } \\
& \text { saat Nabi shallallahu 'alaihi wasallam melewati mereka lagi dan melihat } \\
& \text { hal itu beliau bertanya: 'Ada apa dengan pohon kurma kalian? Mereka } \\
& \text { menjawab; Bukankah anda telah mengatakan hal ini dan hal itu? Beliau } \\
& \text { lalu bersabda: 'Kalian lebih mengetahui urusan dunia kalian.' (HR. Muslim } \\
& \text { - 4358). }
\end{aligned}
$$

Menurut al-Qardhawi hadis tersebut kerap dijadikan dalih untuk menghindar dari hukumhukum syari'at diberbagai bidang ekonomi, politik, sosial dan lain sebagainya. Sebab seperti yang mereka dakwakan, adalah termasuk urusan dunia kita, dan kita lebih mengerti tentangnya. Sedang rasulullah sendiri sudah menguasakan kepada kita. Menurut al-Qardhawi pemahaman seperti itu salah, karena mereka tidak melihat asbabul wurud dari hadis tersebut. ${ }^{14}$

Membedakan antara sarana yang berubah-ubah dan sasaran yang tetap

\footnotetext{
${ }^{13}$ Yusuf al-Qardhawi, Bagaimana Memahami Hadis Nabi . . . ., 131.

${ }^{14}$ Yusuf al-Qardhawi, Bagaimana Memahami Hadis Nabi . . . , 133.
} 
Menurut al-Qardhawi diantara penyebab yang melatarbelakangi kekacauan dan kekeliruan dalam memahami sebuah hadis ialah bahwa sebagian orang telah mencampuradukan antara tujuan yang hendak dicapai oleh hadis dengan prasarana temporer atau lokal yang akdang kala menunjang pencapaian sasaran yang dituju. Padahal siapa saja yang ingin memahami sebuah hadis beserta kandungannya, yang terpenting adalah apa yang menjadi tujuan dari hadis tersebut yang hakiki, itulah yang tetap dan abadi. Sedangkan sarana yang kadangkalanya berubah dengan adanya perubahan zaman, lingkungan, adat, kebudayaan dan sebagainya. ${ }^{15}$

\section{Membedakan antara ungkapan yang bermakna sebenarnya (hakikat) dan yang bersifat majaz}

Untuk memahami teks-teks keagamaan (al-Qur'an dan hadis) diperlukan pengetahuan tentang ilmu-ilmu balaghah seperti ilmu majaz, karena tidak dapat dipungkiri bahwa didalam al-Qur'an maupun hadis terdapat lafaz yang tidak bisa dipahami secara hakiki, untuk menemukan maknya yang sesungguhnya kita harus menggali terlebih dahulu makna lafaz yang majaz (kiasan, metafor). Karena mayoritas ulama telah sepakat bahwa didalam ayat al-Qur'an terdapat ayat yang bersifat hakikat dan majaz. ${ }^{16}$ Begitupun dengan hadis Nabi Saw yang menurut al-Qardhawi Rasul yang mulia adalah seorang yang berbahasa arab dan paling mengusai balaghah. Maka tidak mengherankan jika dalam hadis-hadis-Nya beliau banyak menggunakan lafaz-lafaz yang bermakna majaz. $^{17}$

Majaz yang dimaksud oleh al-Qardhawi ialah yang meliputi majaz lughawiy, majaz aqliy, majaz isti'arah, majaz kinayah, dan berbagai ungkapan lain yang tidak bisa menunjukkan makna sebenarnya secara langsung, tetapi dapat difahami dengan berbagai tanda-tanda yang menyertainya, baik yang sifatnya tekstual ataupun kontekstual. Pemahaman teks berdasarkan majaz merupakan suatu keharusan, bila tidak kita akan tergelincir kepada pemahaman yang keliru dan salah. $^{18}$

\section{Membedakan yang ghaib dan yang nyata}

Tidak dapat dipungkiri bahwa diantara kandungan ayat-ayat al-Qur'an terdapat ayat yang membahas mengenai hal-hal yang ghaib, begitu juga dengan hadis ada hal-hal yang berkaitan dengan alam ghaib, yang sebagiannya menyangkut pembahasan tentang mahluk-mahluk halus

\footnotetext{
${ }^{15}$ Yusuf al-Qardhawi, Bagaimana Memahami Hadis Nabi . . . , 147-148.

${ }^{16}$ Mohammad Nor Ichwan, Memahami Bahasa al-Qur'an, (Yogyakarta : Pustaka Pelajar, 2018), 219.

${ }^{17}$ Yusuf al-Qardhawi, Bagaimana Memahami Hadis Nabi . . , 167.

${ }^{18}$ Nurdin Dihan dan Rosalinda, Metode Pemahaman Hadits Menurut: Muhamamd Al-Ghazali, Yusuf Al-Qardhawi Dan Joseph Schacht, Jurnal HIKMAH, Vol. XIV, No. 2, 2018, 149.
} 
yang tidak dapat dilihat secara kasat mata. Misalnya, seperti pembahasan tentang malaikat ${ }^{19}, \mathrm{jin}^{20}$, dan hal-hal yang berkaitan dengan kehidupan dialam barzah. Yakni kehidupan setelah mati dan kebangkitan dihari kiamat. Menurut al-Qardhawi kewajiban bagi mereka orang muslim untuk menerima hadis-hadis shahih sesuai dengan kaidah-kaidah yang ditetapkan oleh para ulama salaf yang sudah menjadi panutan umat. Dan tidak dibenarkan jika hadis semacam itu ditolak hanya semata-mata karena menyimpang dari akal. ${ }^{21}$

Menurut Yusuf al-Qardhawi adakalanya para ulama menetapkan bahwa agama mebawa kepada hal-hal yang membingungkan akal. Oleh karena itu segala sesuatu yang dinukil dari teks agama (hadis) yang shahih, tidak sekali-kali benrtentangan dengan apa yang dapat dicerna oleh akal. Kalaupun diperkiraan ada pertentangan maka yang demikian itu pasti disebabkan oleh adanya suatu kekeliruan baik dari penukilan yang tidak shahih ataupun kesimpulan akal yang kurang lurus dan gamblang. Oleh karena itu al-Qardhawi menolak pemikiran Mu'tazilah yang tidak menerima hadis-hadis yang membicarakan tentang hal-hal yang ghaib. Seperti penolakan Mu'tazilah terhadap hadis tentang melihat Allah. Bagi Mu'tazilah hal tersebut mustahil dan tidak bisa diterima oleh akal. $^{22}$

\section{Memastikan Makna dan Konotasi Kata-kata dalam Hadis}

Penting bagi kita yang ingin memahami sebuah hadis dengan sebaik-baiknya, memastikan makna dan konotasi kata-kata yang digunakan dalam sebuah hadis, mengingat konotasi pada katakata tertentu adakalanya berubah disetiap masa kemasa, dan dari lingkungan satu ke lingkungan yang lainnya. al-Qardhawi menyebutkan bahwa ada kelompok-kelompok yang menggunakan katakata tertetu dalam sebagai pijakan terhadapak pemaknaan sebuah kalimat. Tentunya tidak ada keberatan sama sekali dalam hal ini, akan tetapi hal tersebut ditakutkan ketika mereka menafsirkan kata-kata dari al-Qur'an atau Hadis. disini timbul kekacauan dan kekeliruan. ${ }^{23}$

Dalam masalah ini al-Qardhawi meberikan sebuah hadis sebagai contoh yaitu hadis tentang pemaknaan kata tashwir (pembuatan gambar) yang disebut dalam hadis shahih, yakni hadis-hadis yang mengecam perbuatan para mushawwir (pembuat gambar) dengan ancaman azab yang

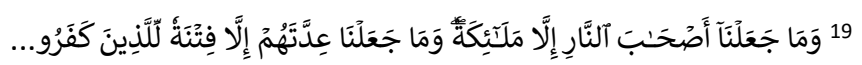

Dan tiada Kami jadikan penjaga neraka itu melainkan dari malaikat: dan tidaklah Kami menjadikan bilangan mereka itu melainkan untuk jadi cobaan bagi orang-orang kafir.(al-Muddatsir [74] : 31).

20

Iblis menjawab: "Demi kekuasaan Engkau aku akan menyesatkan mereka semuanya. kecuali hambahamba-Mu yang mukhlis di antara mereka.(sad [38] : 82-83).

${ }^{21}$ Yusuf al-Qardhawi, Bagaimana Memahami Hadis Nabi . . . , 189.

${ }^{22}$ Yusuf al-Qardhawi, Bagaimana Memahami Hadis Nabi . . . 190.

${ }^{23}$ Yusuf al-Qardhawi, Bagaimana Memahami Hadis Nabi . . , 195. 
sangat pedih. Banyak dari kalangan orang-orang yang menyibukkan diri dengan hadis dan fiqh, memasukkan atau memahami orang yang melakukan pengambilan foto dengan kamera termasuk kepada gologan tashwir yang diharamkan. Pemahaman semacam ini menurut al-Qardhawi salah, dan menanyakan apakah mengambil foto dengan kamera dinamakan mushawwir dan pekerjaan mereka tashwir sudah ada dahulu kala dalam bahasa arab. Sebab seni fotografi belum dikenal pada masa tasyri, maka menurut al-Qardhawi tidak mungkin kata tersebut dalam hadis dimaksudkan kepada ahli foto. ${ }^{24}$

\section{Analisis Hermeneutika Hadis al-Qardhawi.}

Istilah hermeneutika bukanlah suatu hal yang baru dalam wacana interpretasi teks-teks keagamaan (al-Qur'an dan hadis). hermeneutika merupakan istilah yang datang dari Yunani kuno, istilah ini terkait dengan mitologi Yunani dewa Hermes yang merupakan tokoh dalam menyampaikan pesan-pesan ilahi yang sudah dipahaminya lalu kemudian disampaikan kepada manusia. ${ }^{25}$ Maka kemudian hermeneutika diatikan dengan sebuah kegiatan atau kesibukan yang dilakukan oleh seseorang untuk mendapatkan atau menyikap makna dari sebuah teks. Hans Georg Gadamer mengatakan sebagaimana yang dikutip oleh Sahiron Syamsuddin hermeneutika merupakan seni praktis, yakni tecne yang digunakan dalam hal-hal ceramah, menafsirkan bahasa lain, menerangkan dan menjelaskan teks-teks dan sebagai dasar dari seni memahami, sebuah seni yang dibutuhkan ketika makna suatu teks tidak jelas. ${ }^{26}$

Dalam kegiatan penerjemahan bahasa atau alih bahasa dari bahasa asing ke bahasa kita sendiri, sebagai contoh dari bahasa Arab ke bahasa Indonesia, dalam kegiatan penerjemahan tersebut kita terlebih dahulu harus memahami kemudian mengartikulasikan pemahaman kita tersebut kepada orang lain lewat pilihan kata dan rangkaian terjemahan. Penerjemahan bukan sekedar menukar bahasa asing ke bahasa kita melainkan disana ada penafsiran, hal ini cukup menunjukkan bahwa penerjemahan merupakan bagian dari langkah hermeneutika. ${ }^{27}$ Dalam hal ini Nabi Muhammad Saw terlibat penafsiran al-Qur'an dalam dua level, pertama, proses

\footnotetext{
${ }^{24}$ Yusuf al-Qardhawi, Bagaimana Memahami Hadis Nabi . . ., 197.

${ }^{25}$ Budi Hardiman, Seni Memahami : Hermeneutika dari Schleirrmacher sampai Derrida, (Yogyakarta : Kanisius, 2015), 10.

${ }^{26}$ Sahiron Syamsuddin, Hermeneutika dan Pengembangan Ulumul Qur'an, (Yogyakarta : Pesantren Nawesea Press, 2009), 6.

${ }^{27}$ Budi Hardiman, Seni Memahami . . ., 12.
}

e-ISSN 2746-1025 |p-ISSN 2088-6829 | h. 43 
pengungkapan dari bahasa $\operatorname{Tuhan}^{28}$ kedalam bahasa Arab; kedua, prores penafsiran al-Qur'an yang sulit dipahami ketika itu yang kemudian disebut hadis. ${ }^{29}$

Franz Peter Burkard mendefinisikan hermeneutika sebagai penggabungan aktivitas dengan metode penafsiran, ia mengatakan seni menafsirkan teks dan dalam arti yang lebih luar hermeneutika merupakan cerminan teoritis tentang metode-metode dan syarat-syarat pemahaman. ${ }^{30}$ Berdasarkan setatmen yang dikemukan oleh Franz Peter Burkard di atas, maka sebetulnya apa yang telah ditawarkan oleh ulama-ulama terdahulu (salaf) hinggga ulama kontemporer dengan metode dalam memahami teks keagamaan (al-Qur'an dan Hadis) maka setidaknya menurut penulis mereka sudah melakukan salah satu dari proses kerja hermeneutika. Begitu juga dengan metode-metode pemahaman hadis yang ditawarkan oleh al-Qardhawi yang sudah disebutkan di atas secara keseluruhan merupakan bentuk dari proses kerja hermeneutika.

Schleiermacher dalam karyanya hermeneutics and criticism sebagaimana yang dikutip oleh Sahiron Syamsuddin menjelaskan prinsip-prinsip dalam hermeneutikanya dalam dua prinsip, ${ }^{31}$ yaitu : pertama, hermeneutika gramatikal ialah penafsiran yang didasarkan pada analisa bahasa. Menurut Schleiermacher penafsiran yang sukses itu tergantung antara lain talenta dalam memahi bahasa. Kedua, hermeneutika psikologis ialah seseorang yang ingin memahami sebuah teks tidak bisa dengan analisa bahasa saja melainkan penting juga untuk memahami kejiwaan pengarang dari teks tersebut, seorang penafsir harus memahami seluk beluk prngarang teks. Schleiermacher memandang bahwa teks itu merupakan ekspresi diri seseorang, dan ekspresi diri seseorang respon terhadap apa yang ia sedang alami, atau dengan kata lain teks memiliki hubungan apa yang disekitar teks, atau dalam kajian hadis bisa difahami sebagai asbabul wurud yaitu apa yang melatarbelakangi hadis itu lahir. Jika dilihat, nampaknya metode yang ditawarkan Yusuf alQardhawi dalam memahami teks hadis sudah menyentuh konsep hermeneutika Schleiermacher, mulai dari prinsip hermeneutika gramatikal yang terlihat jelas pada poin enam dan delapan dan prinsip hermeneutika psikologis yang nampak pada poin empat yaitu yang melatarbelakangi munculnya hadis.

Sementara itu M. Alim Khoiri dalam jurnalnya ia membaca metode yang ditawarkan oleh alQardhawi dengan hermeneutika Gadamer dan memetakan tiga prinsip Gadamer dalam dalam memahami sebuah teks yaitu (1) past (masa lampau) tempat dimana teks itu dilahirkan, (2) present

\footnotetext{
${ }^{28}$ Semenjak awal turunya wahyu kepada Nabi Muhammad, dari situlah Tuhan berkomunikasi dengan manusia (hambanya). Dalam proses pewahyuan inilah kalam tuhan (prole) beralih kebahasa manusia (language) yang dalam hal ini bahasa Arab terpilih sebagai media konikasi antara Tuhan dan manusia. Baca Toshihko Izutsu, Relasi Tuhan dan Manusia, terj. Agus Fahri Husein dkk, (Yogyakarta : Tiara Wacana Yogya, 1197), 166.

${ }^{29}$ Komaruddin Hidayat, Memahami Bahasa Agama, Sebuah Kajian Hermeneutika, (Bandung : Mizan, 2011 ), 81.

${ }^{30}$ Sahiron Syamsuddin, Hermeneutika . . . , 6.

${ }^{31}$ Sahiron Syamsuddin, Hermeneutika . . . , 35-39.
} 
yang didalamnya berisikan sekumpulan interpreter yang penuh dengan prejudice, (3) future yang didalamnya berisikan nuansa yang baru dan segar yang sifatnya produktif. Menurutnya dengan adanya dialetika antara ketiga metode yang ditawarkan oleh Gadamer diharapkan dapat menarik nalogi historis kontekstual pada masa nabi dengan masa umatnya yang bervariasi. Alim Khoiri menambahkan konsep yang ditawarkan oleh al-Qardhawi dalam memahami hadis Nabi setidaknya telah menyentuh prinsip hermeneutika Gadamer. Tawaran hermeneutis al-Qardhawi dalam memahami hadis sangat terlihat jelasa pada poin keempak dan lima dimana menuru al-Qardhawi untuk mendapatkan makna hadis yang komprehensif harus memperhatikan sebab-sebab khusus yang melatar belakangi munculnya hadis, menurutnya metode yang ditawarkan al-Qardhawi sudah sejalan dengan posedur hermeneutika yakni dengan melakukan ziarah historis. ${ }^{32}$

Apa yang ditawarkan al-Qardhawi dalam memahami dan bagaimana menginternalisasikan hadis Nabi yang sesuai dengan konteks waktu dan tempat sebagaimana yang sudah dijelaskan di atas, maka sebenarnya al-Qardhawi merupakan salah satu ulama yang menawarkan konsep atau cara baca dengan menggunakan hermeneutika, meskipun al-Qardhawi tidak secara langsung mempertunjukkan metodenya sebagai tawaran metode hermeneutika. Menurut Mir'atun Nisa tidak semua metode yang ditawarkan oleh al-Qardhawi menyentuh metode hermeneutik kalau kita teropong lebih jauh dengan triadik hermeneutika yakni : teks, outhor dan reader, sementara alQardhawi belum menyentuh wilayah reader, sehingga menurut Nisa masih arabic centris. ${ }^{33}$

\section{Kesimpulan}

Untuk mendapatkan pemahaman yang komprehensif tentang hadis Nabi, Yusuf al-Qardhawi menawarkan beberapa metode dalam memahami Hadis, sebagaimana yang telah disebutkan diatas. Poin terpenting yang kita dapatkan dari tawaran yang diberikan oleh al-Qardhawi ialah bagaimana kita memahami dan mengaktualisasikan sekaligus menghidupkaan kembali hadis Nabi yang shalih likulli zaman wa maka. Hal tersebut urgen karena tidak bisa dipungkiri bahwa hadis Nabi yang lahir dari tempat dan budaya Arab akan berhadapan dengan tempat dan budaya yang berbeda pula, sehingga perlu pemahaman hadis yang sifatnya produktif. Apa yang telah ditawarkan oleh al-Qardhawi dalam memahami hadis Nabi dengan poin-poin yang telah disebutkan diatas merupakan bentuk kerja hermenetik, meskipun al-Qardhawi tidak secara langsung mempertunjukkan metodenya sebagai tawaran metode hermeneutika.

\footnotetext{
${ }^{32}$ M. Alim Khoiri, Interaksi Dan Pemahaman . . . , 42-43.

${ }^{33}$ Kurdi dkk, Hermeneutika al-Qu'ran dan Hadis...., 449.
} 


\section{Daftar Pustaka}

al-Qardhawi, Yusuf. 2017. al-Halal wa al-Haram Fi al-Islam, Terj Tatam Wijaya, Yogyakarta : Maktabah Wahbah. 1993. Bagaimana Memahami Hadis Nabi, terj Muhammad al-Baqir, Bandung : Karisma. as-Said, Syekh Khalid. 1997. Khitab Yusuf al-Qaradhawi, Kairo : Maktabah Wahbah.

Dihan, Nurdin dan Rosalinda. 2018. Metode Pemahaman Hadits Menurut: Muhamamd Al-Ghazali, Yusuf Al-Qardhawi Dan Joseph Schacht, Jurnal HIKMAH, Vol. XIV, No. 2.

Fatimah, Siti. 2017. Hermeneutika Hadis : Tinjauan Pemikiran Yusuf al-Qardhawi dalam Memahami Hadis, Jurnal REFLEKSI, Vol. 16, No. 1.

Hardiman, Budi. 2015. Seni Memahami : Hermeneutika dari Schleirrmacher sampai Derrida, Yogyakarta : Kanisius.

Hidayat, Komaruddin. 2011. Memahami Bahasa Agama, Sebuah Kajian Hermeneutika, Bandung: Mizan.

Ichwan, Mohammad Nor. 2018. Memahami Bahasa al-Qur'an, Yogyakarta : Pustaka Pelajar. Izutsu, Toshihko. 119. Relasi Tuhan dan Manusia, terj. Agus Fahri Husein dkk, Yogyakarta : Tiara Wacana Yogya.

Khoiri, M. Alim. 2018. Interaksi Dan Pemahaman Hadis Telaah Hermeneutis Pemikiran Yusuf alQaradawi, Jurnal Universum, Vol. 12, No. 1.

Kurdi dkk. 2010. Hermeneutika Alquran dan Hadis, disunting oleh Sahiron Syamsuddin Yogyakarta: eLSAQ Press.

Syamsuddin, Sahiron. 2009. Hermeneutika dan Pengembangan Ulumul Qur'an, Yogyakarta : Pesantren Nawesea Press.

Shalih, Sulaiman ibn. t.t. Al-Qaradhawi fil Mizan, Riyadl: Dar al-Jawab.

Qudsy, Saifuddin Zuhri Subkhani Kusuma Dewi. 2018. Living Hadis Praktik, Resepsi, Teks, dan Transmisi, Yogyakarta : Q-Media. 